\title{
Measuring partisan polarization with partisan differences in satisfaction with the government: the introduction of a new comparative approach
}

\author{
Veronika Patkós ${ }^{1}$
}

Accepted: 9 February 2022 / Published online: 27 February 2022

(c) The Author(s) 2022

\begin{abstract}
In recent years, the attention of political scientists investigating political polarization has turned from the ideological aspects of polarization to its partisan and affective aspects. This recent turn implied that this area has experienced an urgent need to create appropriate polarization indices that are backed with high-quality data across time and countries to carry out comparative research. This paper argues that existing polarization indices mostly fail to adequately include the most important aspect of polarization, that is, bimodality. To fill this gap, it proposes a partisan polarization index using European Social Survey data on government satisfaction of partisan camps, which is available for 32 European countries between 2002 and 2020 for all in all 214 country-years. That is, the paper offers an insight into trends in partisan polarization for these 214 cases. The analysis of cases shows that in the last two decades polarization hit mostly Southern European countries and some EastCentral European ones, like Cyprus, Spain, Greece, Turkey, Poland and especially, Hungary. Within the realm of possibilities, the paper compares the newly constructed index to other polarization indices.
\end{abstract}

Keywords Partisan polarization · Europe $\cdot$ Measurement $\cdot$ European social survey

\section{Introduction}

During the last decade, the topic of political polarization has received growing interest from political science researchers. Evidence shows that strong political dividedness does not generate from and hence is not necessarily linked to ideological polarization and disagreement over specific policy issues. Based on these findings, scholars' attention has recently turned toward an explicitly partisan, affective component of polarization (Boxell et al. 2020; Knudsen 2020; Lauka et al. 2018; Reiljan 2020; Wagner 2020). Despite this growing interest, the empirical research on affective and partisan aspects of polarization remained a challenge, as comparative data on polarization is

Veronika Patkós

patkos.veronika@tk.hu

1 Centre for Social Sciences, Institute for Political Science, Budapest, Hungary 
not easily available, and a scholarly consensus about how to measure these important aspects is still lacking. Additionally, as almost all works concerning affective-partisan aspects of polarization mention, the field is characterized by a heavy focus on American polarization. This is problematic for scholars interested in multi-party systems, because works concentrating on polarization in the context of the US use the Democrat-Republican divide as a starting point to construct polarization indices, and this practice is not directly transferable to European systems.

This paper intends to offer a new strategy to measure partisan polarization that can easily be constructed with commonly queried survey data and that can be used in comparative research. The construction of the new index is motivated by both theoretical and methodological reasons. Partisan polarization indicates the extent to which the political life of a community can be described as a battle between two partisan sides. To assess affective-partisan aspects, the majority of former works uses affect toward single parties as the main input variable to construct a polarization index, and they construct their indexes with an 'aggregative' approach, considering all voters' evaluations on their in-party and out-parties. I argue that these aggregative methods fail to adequately include the aspect of bimodality, that is, the actual existence of two hostile political camps, which is an ultimate feature of severe (partisan) polarization. To include the aspect of bimodality, this paper considers elements from the American tradition of polarization research, assuming that in polarized contexts competing camps tend to see their in-group in a positive light and their out-group members in a negative light. Based on this notion, it calculates partisan polarization based on respondents' satisfaction with their national government, by comparing the average satisfaction of cabinet supporters (who evaluate the government as a part of their in-group) to the average satisfaction of opposition supporters (who evaluate the government as a part of their out-group) for each country case.

Methodologically, the few existing attempts that provide tools to assess dividedness rely on feeling thermometers toward parties, which is not a commonly queried item in cross-national surveys. Practically, when applying an above described 'aggregative' method to assess affective polarization, scholars must resort to use the Comparative Study of Electoral System's data (CSES) (Lauka et al. 2018; Reiljan 2020; Wagner 2020), or to aggregate national survey data coming from different sources for each country (for a solution that combines these two methods see Boxell et al. 2020). The CSES is an extremely useful dataset for political science researchers, although it offers limited room for the comparative investigation of European systems, mainly if one has longitudinal research ambitions. Hence, this paper uses data from the European Social Survey and computes polarization indices in 32 European countries between 2002 and 2020 in nine data rounds, for all in all 214 country-years. This way, it enables us to make both temporal and cross-country comparisons about polarization in European countries. The structure of the paper is as follows. First I discuss what this research means by partisan polarization, and why we need a new index to assess this aspect. Then I introduce a new partisan polarization index (PPI) and I describe it by reporting the most and least polarized cases between 2002 and 2020 over Europe. A temporal and regional comparison of the index is also provided. In the last section, to demonstrate the intuitiveness of the newly constructed polarization index, I provide correlations of PPI with other types of political polarization indices. 


\section{Why do we need a new measurement strategy?}

\subsection{What is a 'partisan aspect' of political dividedness?}

Based on former research, it is evident that apart from ideological differences there is another, and possibly more important, partisan aspect of political dividedness that characterizes political systems (Iyengar et al. 2012; Lauka et al. 2018; Reiljan 2020). A (primarily) non-ideological type of dividedness is captured with labels like partisan polarization (Baldassarri and Gelman 2008; Jacobson 2010, 2003; Lauka et al. 2018; Stoker and Jennings 2008), affective polarization (Boxell et al. 2020; Druckman and Levendusky 2019; Gidron et al. 2019; Hernandez et al. 2020; Knudsen 2020; Reiljan 2020; Wagner 2020), behavioral polarization (Mason 2013) partyism, tribalism or factionalism (Goldstone and Ulfelder 2004). Others concentrate on the individual-level components of such dividedness, that is, on partisan animosity (Orr and Huber 2020; Street et al. 2016), partisan bias (Anduiza et al. 2013; Bartels 2002; Jerit and Barabas 2012), partisan prejudice (Lelkes and Westwood 2017) or negative partisanship (Rose and Mishler 1998). The essence of all of these concepts is that they are rooted in strong partisan identities (be them positive, negative, or both), instead of in ideological differences. Partisan polarization is often characterized by substantial ideological differences between the competing groups, but deep ideological differences are neither necessary nor sufficient elements of severe partisan polarization (DiMaggio et al. 1996; Iyengar et al. 2012; Lauka et al. 2018; Patkós 2019; Reiljan 2020; Slater and Arugay 2018).

\subsection{The importance of bimodality in the concept and measurement of partisan dividedness}

Severe partisan polarization takes place when partisan identities increasingly act as a social identity (Fiorina et al. 2005; Lauka et al. 2018), contributing to hostility and distrust for the out-party and unconditional loyalty for the in-party (Iyengar et al. 2012; Körösényi 2013; Lauka et al. 2018; Mason 2015; McCoy et al. 2018; Patkós 2019; Reiljan 2020; Wagner 2020), which groups may be constituted by more than one party. That is, in these cases, partisan bias in voters' evaluations is very strongly present, leading to a tribal style in politics (Green et al. 2004; Mason 2015; McCoy et al. 2018). Competing sides see the other party as one threatening their values, lifestyle or existence (McCoy et al. 2018; Street et al. 2014).

Elections are viewed as high-stake occasions, where majority rules and results are highly consequential, as winners win the opportunity to fit the country to their taste with little or no compromise. Campaigns often go nasty, as the stakes are high and both sides tend to think that the ends justify the means. Everyday politics also is a zero-sum game, with the constant sensation that the future of the country is at stake, which contributes to a need to win over the other camp in every situation and to reject consensus with the other side (Goldstone and Ulfelder 2004; Hetherington 2009; Körösényi 2013; Mason 2015; Street et al. 2014; Ward and Tavits 2019).

The above features of polarized systems suggest that severe polarization is always characterized by a strong bimodal aspect, (Baldassarri and Gelman 2008; DiMaggio et al. 
1996; Esteban and Ray 1994; McCoy et al. 2018; Patkós 2019; Somer and McCoy 2019; Wagner 2020) as it simplifies political conflict to a battle of 'Us' and 'Them', good and evil. While in some political systems there are more than two competing poles or there are considerable tensions between ideologically extreme groups, these conflicts do not organize the political life of a community into the battle of two groups, hence these countries do not turn into a severely polarized society.

To sum up, I use the term partisan polarization to indicate the extent to which the political life of a community can be described as a battle between two partisan sides. This concept, admittedly, overlaps with affective polarization, which sometimes is defined in a very similar way to the above (see for example Wagner (2020) and Lauka et al. (2018)). However, affective polarization is mainly used to measure positive feelings towards partisans of one's in-group (or own party) and negative feelings towards partisans of the outgroup (or out-party) ${ }^{1}$ in an 'aggregative' manner. Hence, it is closer to voters' personal feelings, and it almost always refers to a kind of sum of all voters' all negative and positive evaluations. While researchers of affective polarization consider bimodality to be important, measurement strategies concentrate more on the dispersion of likes and dislikes in a political community toward parties, and much less on bimodality. Even if they consider the size of parties that individuals like or dislike, this is not exactly the same thing as detecting the existence of two partisan sides, as it is not sensitive to the actual existence of political camps, only to the overall proportion of likes and dislikes.

Although strongly related to affective positions of citizens, partisan polarization indicates something more than a mere sum of individual likes and dislikes, as its main interest is whether these likes and dislikes are clustered around two poles. That is, here I suggest using the term partisan polarization when referring to strong bipolar tendencies on the system level and to the presence of two hostile political camps. The term affective polarization could be saved for cases when system-level bimodality is not in the main focus of the research, like for investigations that focus on the dispersion of personal affective positions toward parties, or on the effect of politics on their private life (see for example the interparty marriage measures of affective polarization: Iyengar et al. 2012; Knudsen 2020).

\subsection{Considering bimodality_-Integrating lessons from the American research tradition}

Investigating partisan polarization in the US has a long tradition that relies on measuring the gap between the opinion of Democrats and Republicans in some politics' related questions (Bafumi and Shapiro 2009; Baldassarri and Gelman 2008). That is, partisan polarization is generally calculated by using the gap between the evaluations of Democrats and Republicans on the performance of the President, the performance of the economy or some more specific policy measures (Bartels 2002; Bisgaard 2015; Jacobson 2010; Jerit and Barabas 2012; Shani 2009). Positions on specific policy measures cannot properly mirror differences in overall evaluations across time and countries, that is, here we should find a general question having a strong partisan relevance, such as the performance

\footnotetext{
1 Knudsen (2020) and Druckman and Levendusky (2019) investigate different aspects of affective polarization on voters' and parties' level separetaly. While a considerable part of former results on affective polarization may apply both to voter-level and party-level affective polarization, they show that these are related yet somewhat distinct features of national politics.
} 
of the President in the US (Jacobson 2013, 2003). As European systems tend to be nonpresidential, the general performance question that I use concerns the work of the national government.

The other important difference between European systems and the US, the DemocratRepublican divide versus systems with a variety of parties, is trickier to solve. Recent works had different solutions to the evident challenge of transfer polarization indices constructed to describe the relationship between two partisan camps to multiparty contexts. However, it is important to stress that, no matter the number of parties in a party system, polarization remains ultimately a bipolar phenomenon. According to this notion, the majority of scholars who empirically investigate polarization simplifies multi-party contexts in such ways that transform multi-party competition into the competition of two political camps. Traditionally, the Republican-Democrat divide is substituted with a left-right divide, but this approach is not useful when turning to partisan divisions instead of ideological ones. Other solutions to the problem are to restrict the investigation to the so-called top-two parties, that is, considering the biggest incumbent and opposition parties only (Boxell et al. 2020). Another possibility is to define blocs based on the government/opposition status of parties, that offers a straightforward categorization of parties in political competition (Knudsen 2020; and see a similar solution by Martini and Torcal 2019). Analyzing the post-communist area, Frye (2002) uses the seat share of the largest ex-communist faction when an anti-communist holds the executive (and vice versa) to calculate polarization, that lies somewhere between the ideological and partisan approaches.

When constructing a partisan polarization index, I follow the approach used by Knudsen (2020) as this approach is the most similar to the Democrat-Republican divide that lies behind American polarization research practices, and at the same time, it considers the differences between the political characteristics of European polities and the US. That is, the index provided here to assess partisan polarization is based on the idea of dividing the average satisfaction of cabinet supporters by the average satisfaction of opposition supporters. PPI can thus be computed with the following expression. $X$ measures satisfaction with the government. We take the mean of this variable for two groups: the supporters of the government and the supporters of the opposition in each country. Then PPI is:

$$
P P I=\frac{a v g_{g o v}(X)}{a v g_{o p p}(X)}
$$

While these satisfaction scores may contain evaluations about single policy decisions, the evaluation of the government is strongly related to previously established beliefs and partisan identities. If a context is strongly polarized, the government itself embodies the out-group for opposition partisans and the in-group for government partisans. In nonpolarized context we could expect more nuanced evaluations, as these context do not presuppose unconditional loyalty from the in-group members and genuine rejection and distrust from the part of out-group members. Hence, a 'winner-loser gap' on the performance of the national government can be used as a predictor of partisan polarization in multiparty systems (Patkós 2019; Stanig 2013).

Comparing the mean satisfaction scores of opposition supporters to that of government supporters has advantages both over techniques that consider top-two parties' voters only and that try to consider all parties' supporters' opinion about all single parties. Compared to the latter group of measurement strategies, questions related to the presence of smaller parties - such as the inclusion of smaller parties in survey questions or additional weighting by party dimensions - do not arise, as every respondents' opinion is included in the 
index. Variations in the size or ideological position of parties are also not a problem - the only question is whether the respondents' preferred party is a coalition or opposition party during the period of the interview. Compared to measures constructed based on the evaluations of voters of the top-two, the data loss is evidently smaller in this case, as using this practice includes the opinion of all voters, not only those of the two biggest parties.

Similarly to the Democrat-Republican divide, the government/opposition categories fundamentally reflect 'who are with whom' on the political scene of the given country. Although the different aspects of political polarization are correlated and therefore the left-right divide is also able to capture some parts of partisan polarization, comparing evaluations of government/opposition partisans reflects the nature of the political competition more correctly than the left/right categories. This is especially true if a government has a two-sided opposition. Even if opposition parties are ideologically very far from each other, the evaluations of their voters about the performance of the government may be very similar. Moreover, using the government/opposition categories, the position of any party in almost all time periods is unquestionable, (except for the time between elections and the investiture of the new government, and cases when non-partisan technocratic governments are in office, which are uncommon). Thus, this method offers a straightforward categorization of parties - and subsequently, voters - into two groups which does not apply to the left/ right divide. This way, we can directly include the aspect of bimodality in the measurement strategy, which, although it has been a crucial element in the conceptualization of affective and partisan polarization, has remained relatively out of former operationalizations.

\subsection{Widening the pool of data used for polarization research}

Existing methods to assess affective-partisan types of dividedness typically use respondents' evaluations about parties measured on feeling thermometers (Boxell et al. 2020; Knudsen 2020; Lauka et al. 2018; Reiljan 2020; Wagner 2020). However, these items are not commonly queried in comparative surveys. An exception is the Comparative Study of Electoral System's data (CSES), which is an important common input data source of existing polarization indices. It offers data for 178 country-cases (from these 111 are European cases) in five modules between 1996 and 2021. The need for feeling thermometer questions to construct polarization indices strongly limits the possibilities of researchers to actively select their samples (instead of relying on the pool of the CSES data) or to compare their results to data from other sources. Moreover, although the CSES is an exceptionally helpful data source to analyze electoral behaviour, due to its election-based structure it is not the best empirical input to carry out country-level multivariate analysis, as it offers a heavily unbalanced data panel with a large number of countries over a relatively long time period, although including only some data points (at maximum 5, on an average 3.18) for each country. Therefore, the above-mentioned attempts that rely on this dataset when calculating partisan or affective dividedness are restricted to a relatively small and extremely heterogeneous sample in terms of place and time, which offers a very limited possibility for longitudinal analysis. For these reasons, I find it urgent to consider other datasets to be used for investigating polarization.

A promising possibility is to use the nine currently available data rounds of the European Social Survey project (European Social Survey) which is another widely used, freeto-access, comparative social scientific database with a large set of relevant questions about political values, choices and behavior, although it does not contain feeling thermometer data. As it focuses on European societies, its data pool is less heterogeneous than the one 
offered by the CSES. To date, it includes nine biannual data rounds from 32 countries between 2002 and 2020, with all in all 214 country-years. 12 countries (Belgium, Switzerland, Germany, Spain, France, Finland, the United Kingdom, Hungary, the Netherlands, Norway, Poland and Sweden) are present in all nine existing data rounds, which offers a decent pool for comparison and for exploring trends in itself.

Turning to its potentials for longitudinal research, the ESS offers a less unbalanced panel with significantly more data points for each participant country (countries are included 6.68 times on an average in the ESS, compared to 3.18 for the CSES), which are closer to each other in time, due to the biannual structure of the data set. Comparing future perspectives, as the CSES modules concentrate on five-year intervals, and the ESS is queried in every two years, the latter is expected to grow more dynamically than the CSES, which means that the divergence between their significance in cross-sectional time series analysis will probably widen over time.

\section{Data and variables}

When constructing the index, first I identified respondents of the ESS datasets as government or opposition supporters. Currently, the ESS has nine biannual data rounds, and for the first eight data rounds a categorization on the government/opposition preferences of respondents is available in the European Government-Opposition Voters (EGOV) Data Set (Patkós and Plesz 2021). This supplementary data set provides two dummy variables on government/opposition preferences. The first one identifies opposition and government voters based on their last vote choice ("Votedforwinner" in the original data set, which uses the vote of respondents cast at the last national elections as input variable. It is 1 if the respondent voted for a government party and it is 0 if he or she voted for an opposition party). The second one differentiates between opposition and government parties' identifiers based on respondents' self reported party identification ("Closetowinner" in the original data set, which uses the variable indicating which party a respondent feels close to as input variable. It is 1 if the respondent feels close to a government party and it is 0 if he or she feels close to an opposition party). For the ninth data round, the same classification was constructed according to the documentation of the EGOV Data Set.

As partisan polarization is strongly rooted in group identities, PPI is calculated based on the responses of identifiers (those who felt close either to an opposition or a government party), however, I introduce the results calculated by using data from those who reported their last vote choice as well, this index is called PPI(voters). Partisanship and voting decisions are closely related in European systems (Dalton and Weldon 2007). The correlation between identifiers' and voters' polarization indices is 0.95 , meaning that they are practically interchangeable in a country level analysis and that depending on the premises and purposes of the research and the accessibility of data, PPI(voters) is a fair alternative to PPI. Aspects to consider are that vote choice is more volatile than party identification, that respondents are more likely to vote for than to feel close to a specific party, and that they are also more willing to report their vote choice than their partisan identity. This means that the variable on vote choice has less missing values, although in itself it refers to a less intense preference from the part of the respondent than the one indicating partisan identity. Lastly, vote choice refers to a past decision, while party identification refers to the present. 
Table 1 European countries' PPI averages between 2002 and 2020

\begin{tabular}{|c|c|c|c|}
\hline Country & Mean & $\mathrm{N}$ of rounds & Std. Deviation \\
\hline$A T$ & 1.43 & 6 & 0.40 \\
\hline$B E$ & 1.19 & 9 & 0.12 \\
\hline$B G$ & 2.00 & 5 & 0.35 \\
\hline $\mathrm{CH}$ & 0.98 & 9 & 0.03 \\
\hline$C Y$ & 2.01 & 5 & 1.01 \\
\hline$C Z$ & 1.52 & 7 & 0.32 \\
\hline$D E$ & 1.37 & 9 & 0.16 \\
\hline$D K$ & 1.57 & 7 & 0.11 \\
\hline$E E$ & 1.45 & 8 & 0.30 \\
\hline ES & 2.18 & 9 & 0.69 \\
\hline$F I$ & 1.22 & 9 & 0.17 \\
\hline$F R$ & 1.72 & 9 & 0.29 \\
\hline$G B$ & 1.63 & 9 & 0.10 \\
\hline$G R$ & 2.53 & 4 & 0.69 \\
\hline$H R$ & 2.28 & 3 & 0.29 \\
\hline$H U$ & 2.66 & 9 & 0.80 \\
\hline$I E$ & 1.53 & 8 & 0.24 \\
\hline$I L$ & 1.50 & 6 & 0.22 \\
\hline$I S$ & 2.09 & 2 & 0.17 \\
\hline$I T$ & 1.74 & 4 & 0.28 \\
\hline$L T$ & 1.25 & 5 & 0.36 \\
\hline$L U$ & 1.10 & 2 & 0.17 \\
\hline$N L$ & 1.27 & 9 & 0.11 \\
\hline$N O$ & 1.42 & 9 & 0.03 \\
\hline$P L$ & 2.27 & 9 & 0.53 \\
\hline$P T$ & 1.74 & 8 & 0.43 \\
\hline$R U$ & 1.38 & 5 & 0.07 \\
\hline$S E$ & 1.44 & 9 & 0.13 \\
\hline$S I$ & 1.59 & 8 & 0.63 \\
\hline$S K$ & 1.65 & 6 & 0.20 \\
\hline$T R$ & 2.42 & 2 & 0.24 \\
\hline$U A$ & 1.89 & 5 & 0.50 \\
\hline Total & 1.64 & 214 & 0.55 \\
\hline
\end{tabular}

Table 1 shows the average level of polarization for the 32 countries analyzed between 2001 and 2020. Appendix 1 shows the values of PPI and PPI(voters) for all country-years.

Among the least polarized countries, we find Switzerland, Luxembourg, Belgium, Finland, the Netherlands and Germany. Ireland, Denmark, Slovenia, the United Kingdom, Slovakia, France, Italy and Portugal present average levels of polarization, while the most strongly polarized are Spain, Croatia, Turkey, Poland, Greece and Hungary. 
Table 2 Correlation between polarization indices

\begin{tabular}{|c|c|c|c|c|c|c|}
\hline & MPP & MAP & Reiljan-AP & PPI-voters & PPI & PP-Vdem \\
\hline \multirow[t]{2}{*}{ MAP } & $0,465^{* * *}$ & & & & & \\
\hline & 32 & & & & & \\
\hline \multirow[t]{2}{*}{ Reiljan-AP } & 0,031 & $0,681^{* * * *}$ & & & & \\
\hline & 19 & 21 & & & & \\
\hline \multirow[t]{2}{*}{ PPI-voters } & 0,325 & 0,358 & $0,465^{* *}$ & & & \\
\hline & 20 & 20 & 23 & & & \\
\hline \multirow[t]{2}{*}{$P P I$} & 0,273 & $0,398^{*}$ & $0,418^{* * *}$ & $0,954^{* * *}$ & & \\
\hline & 20 & 20 & 23 & 186 & & \\
\hline \multirow[t]{2}{*}{ PP-Vdem } & $-0,297$ & $-0,030$ & 0,039 & $0,438^{* * *}$ & $0,496^{* * *}$ & \\
\hline & 21 & 24 & 24 & 165 & 165 & \\
\hline \multirow[t]{2}{*}{ SP-Vdem } & 0,262 & 0,170 & $0,416^{* * *}$ & $0,317^{* * *}$ & $0,379^{* * *}$ & $0,726^{* * *}$ \\
\hline & 24 & 28 & 29 & 186 & 186 & 543 \\
\hline
\end{tabular}

$* * * p<.01, * * p<.05, * p<.1$

Fig. 1 PPI averages of 12 European countries participating in all nine ESS rounds

Fig. 2 Biannual variations in the level of PPI in three polarized countries for the nine ESS rounds
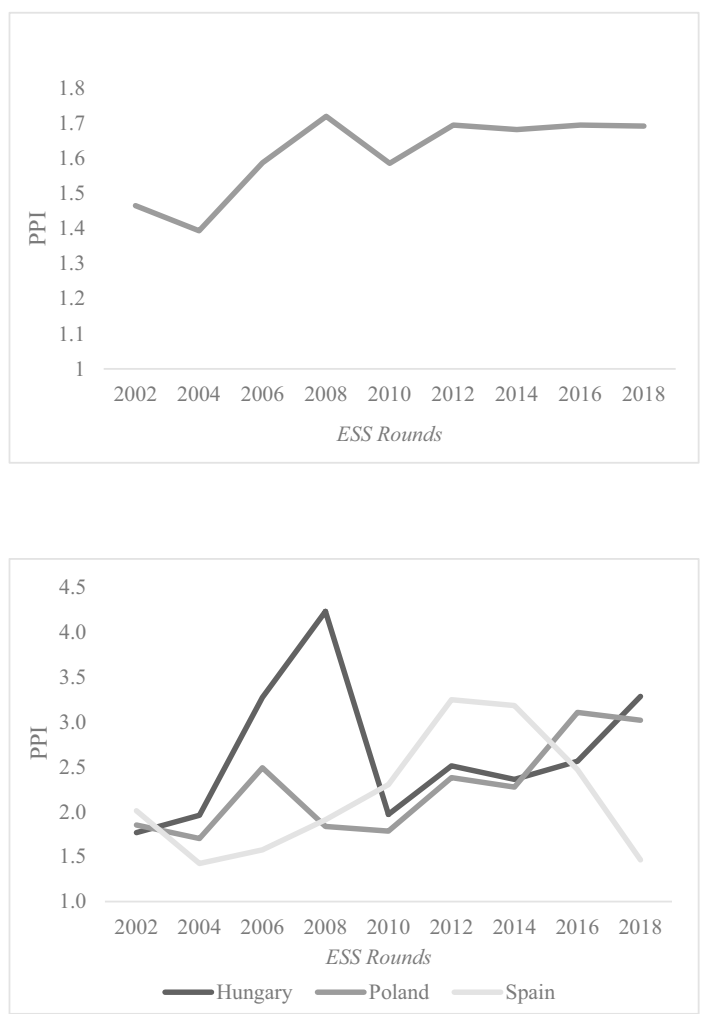
Table 2 shows temporal changes of polarization, based on the averages of the 12 countries participating in all nine ESS rounds so far, Belgium, Switzerland, Germany, Spain, France, Finland, the United Kingdom, Hungary, the Netherlands, Norway, Poland and Sweden. While it is a widely shared view that polarization is rising worldwide, in the case of these 12 European democracies, based on the picture offered by Fig. 1, this trend is not supported. Polarization was indeed somewhat milder in the first two ESS rounds, but since 2006, polarization averages remained around $1.6-1.7$ points, with practically no difference between the values obtained in the last four rounds. That is, based on data from 12 countries out of which we find traditionally weakly polarized (Belgium, Finland and Switzerland) and strongly polarized (Hungary, Poland, Spain) countries as well, we cannot observe a growing trend in polarization during the last decade, and neither a declining one.

That said, it is important to draw attention to the diverging trends experienced by different countries. Figure 2 shows an example of how PPI varied over time in three of the most polarized cases included in all nine ESS rounds, Spain, Poland and Hungary. Out of these three cases, in the last ten years, Poland and Hungary have presented a picture of strong and constantly growing polarization, while polarization in Spain started to plummet after 2012 and now its level is around the average of all country- years analyzed here. While it participated in five rounds only, also Lithuania has experienced a notable decrease in terms of partisan polarization (1.88 to 1.06) between 2011 and 2019. The qualitative analysis of these cases is an important task for future works that could strongly enhance our knowledge about the dynamics of polarization.

\subsection{The correlates of PPI and other polarization indices}

In this part, I turn to the correlates of the newly presented index and some other polarization indices. As noted above, the majority of affective or partisan polarization indices is composed by using CSES data, where attitudes toward relevant parties are measured on a feeling thermometer. PPI and PPI(voters) are compared to five other polarization indices. In all cases, higher values indicate stronger polarization.

- Reiljan's affective polarization index (Reiljan-AP), ranges from 2.69 to 6.68

- Lauka et al. (2018) mass partisan polarization index (LFM-MPP), that ranges from 0.01 to 0.39

- Lauka et al. (2018) mass affective polarization index (LFM-MAP), that ranges from 0.06 to 0.54

- Political polarization as measured in the V-Dem project (VDem-PP). This index is measured with the question "Is society polarized into antagonistic, political camps?", answers range from 0 (not at all) to 4 (to a large extent) (Pemstein et al. 2018).

- Social polarization as measured in the V-Dem project (VDem-SP). The index is measured with the question "How would you characterize the differences of opinions on major political issues in this society?", that is, this question is somewhat closer to ideological polarization than to affective/partisan polarization. Answers are recoded to 
range between 0 (no polarization) to 4 (serious polarization) (Mechkova et al. 2019; Pemstein et al. 2018).

The direct comparison of PPI and CSES-based polarization indices is almost impossible as there is hardly any overlap between the ESS and CSES data sets (4 data points in the case of LFM-MPP and LFM-MAP and 5 data points in the case of Reiljan-AP). Bearing in mind that this practice is likely to show weaker relationships than they would be in case of adequate data, I matched R-AP, LFM-MPP and LFM-MAP indices with PPI indices registered in the previous or following years, as available.

Entries are Pearson correlation coefficients with the number of observations below. Italicized values indicate that data points between the two variables were matched with a one year shrink, due to the unavailability of data.

That is, when examining correlation coefficients for PPI and the above three indices computed on CSES data is important to consider that annual differences in PPI might be notable (the correlation coefficient between PPI and PPI's first lag is $r=0.72(p=0.000$; $\mathrm{N}=138)$ ), and that sample sizes are really small. That said, the correlation coefficients indicating the relationship between Reiljan-AP and both PPI and PPI(voters) are quite substantial, and they are highly significant. In the case of the two polarization variables constructed based on expert survey data (PP-Vdem and SP-Vdem), the correlation is similar and highly significant. The new partisan polarization indices are in a stronger relationship with political polarization (PP-Vdem) than with social polarization (SP-Vdem), which conforms to differences in their conceptualization.

Interestingly, LFM-MPP and Reiljan-AP, although calculated using the same data and having a similar conceptual basis, are empirically unrelated. LFM-MPP is not significantly related to PP-Vdem and SP-Vdem, nor to PPI and PPI(voters) indices. Moreover, in the case of PP-Vdem and both LFM-MPP and LFM-MAP the direction of the relationship is surprisingly negative (yet again, on this small sample it is insignificant). This negative result supports the assumption that 'aggregative' polarization indices might not reflect well the aspect of bimodality (again, PP-Vdem is measured with the question "Is society polarized into antagonistic, political camps?").

To sum up, despite the one-year shrink in most data points, Reiljan-AP and PPI and PPI-voters are moderately related and the newly constructed variables are in a moderate, highly significant positive relationship with the two polarization indices of the V-Dem project as well. Between the new indices and Lauka et al. (2018) indices, the correlation coefficients indicate a moderate-low level relationship, although, on this small sample, the relationship is not significant in most cases, except for that between LFM-MAP and PPI. 


\section{Conclusion}

In this paper, I introduced a new measurement strategy to assess partisan polarization in European countries based on ESS data, which is constructed based on the evaluations of partisans of coalition blocs and opposition blocs in each country-case. Comparing this strategy to former attempts, the present method directly considers the aspect of bimodality which is a crucial (if not the single most important) aspect of polarization. From a methodological aspect, the present project aimed at providing an alternative also for those who seek to assess partisan polarization in European countries but find the coverage of the CSES - which is the most commonly used data set to assess affective/partisan aspects of dividedness to date - inadequate for their purposes. For example, for researchers interested in the formation, causes or consequences of polarization the CSES data is not the best source, due to its election-based data structure and constantly changing set of participating countries. In contrast, the ESS offers a somewhat more stable group of participating countries, and data releases are more frequent (in every two years), compared to the fiveyear time window of CSES modules. This data structure produces more usable aggregated country-level data - such as partisan polarization of the electorate - to carry out international comparisons and time-series analysis. In order to quantitatively study the dynamics and drivers of polarization, the index can be merged with country-level aggregated data or general macro data.

The correlation analysis showed that the present indices are significantly linked to expert surveys' polarization estimations on political and social polarization from the V-Dem project. The new indices were also significantly correlated to Lauka et al. (2018) mass affective polarization index and to Reiljan's (2020) affective polarization index, even if we matched data coming from different surveys with a one-year shrink. The correlation coefficients show moderate level relationships. Lastly, the analysis showed no important differences between the two new polarization indices, PPI and PPI(voters). This means that in future research, if data about identifiers is unavailable, an index constructed using responses from voters may be a rational, well-comparable compromise.

The paper contributes to the literature also with some descriptive findings about the level and variations in polarization among European countries. According to these results, in the last two decades, strong partisan polarization has been present in most of the Southern European country-cases and some East-Central European ones, like Cyprus, Spain, Greece, Turkey, Poland and especially, Hungary. Another important finding is that polarization remained more or less constant on an average during the last decade, without showing important increases or decreases at an overall European level. That said, on the level of individual countries we did observe substantial variations between 2002 and 2020: after a peek in 2013, partisan polarization became milder in Spain, turning to normal levels, while after 2010, Poland and Hungary have experienced a period of deepening dividedness.

\section{Appendix}

See Table 3 
Table 3 PPI and PPI (voters) by country, year and ESS round

\begin{tabular}{|c|c|c|c|c|c|}
\hline Country & Country ID & ESS round & Year & PPI(voters) & PPI \\
\hline Austria & AT & 1 & 2003 & 1.744 & 2.014 \\
\hline Austria & AT & 2 & 2005 & 1.652 & 1.821 \\
\hline Austria & $\mathrm{AT}$ & 3 & 2007 & 1.074 & 1.063 \\
\hline Austria & $\mathrm{AT}$ & 7 & 2014 & 1.370 & 1.318 \\
\hline Austria & $\mathrm{AT}$ & 8 & 2016 & 1.374 & 1.333 \\
\hline Austria & AT & 9 & 2018 & 1.077 & 1.057 \\
\hline Belgium & $\mathrm{BE}$ & 1 & 2002 & 1.094 & 1.134 \\
\hline Belgium & $\mathrm{BE}$ & 2 & 2004 & 1.146 & 1.119 \\
\hline Belgium & $\mathrm{BE}$ & 3 & 2006 & 1.029 & 1.030 \\
\hline Belgium & $\mathrm{BE}$ & 4 & 2008 & 1.132 & 1.156 \\
\hline Belgium & $\mathrm{BE}$ & 5 & 2010 & 1.157 & 1.107 \\
\hline Belgium & $\mathrm{BE}$ & 6 & 2012 & 1.187 & 1.157 \\
\hline Belgium & $\mathrm{BE}$ & 7 & 2013 & 1.332 & 1.364 \\
\hline Belgium & $\mathrm{BE}$ & 8 & 2016 & 1.285 & 1.367 \\
\hline Belgium & $\mathrm{BE}$ & 9 & 2018 & 1.214 & 1.265 \\
\hline Bulgaria & BG & 3 & 2006 & 1.703 & 1.967 \\
\hline Bulgaria & BG & 4 & 2009 & 1.972 & 2.244 \\
\hline Bulgaria & BG & 5 & 2010 & 1.598 & 1.914 \\
\hline Bulgaria & BG & 6 & 2013 & 1.855 & 2.380 \\
\hline Bulgaria & BG & 9 & 2018 & 1.424 & 1.474 \\
\hline Switzerland & $\mathrm{CH}$ & 1 & 2002 & 1.009 & 0.982 \\
\hline Switzerland & $\mathrm{CH}$ & 2 & 2004 & 1.001 & 0.947 \\
\hline Switzerland & $\mathrm{CH}$ & 3 & 2006 & 1.065 & 1.023 \\
\hline Switzerland & $\mathrm{CH}$ & 4 & 2008 & 0.967 & 0.938 \\
\hline Switzerland & $\mathrm{CH}$ & 5 & 2010 & 1.071 & 0.968 \\
\hline Switzerland & $\mathrm{CH}$ & 6 & 2012 & 0.990 & 1.005 \\
\hline Switzerland & $\mathrm{CH}$ & 7 & 2014 & 1.000 & 0.959 \\
\hline Switzerland & $\mathrm{CH}$ & 8 & 2016 & 0.955 & 0.970 \\
\hline Switzerland & $\mathrm{CH}$ & 9 & 2018 & 1.000 & 0.993 \\
\hline Cyprus & $\mathrm{CY}$ & 3 & 2006 & 1.253 & 1.272 \\
\hline Cyprus & $\mathrm{CY}$ & 4 & 2008 & 1.196 & 1.271 \\
\hline Cyprus & $\mathrm{CY}$ & 5 & 2009 & 1.734 & 1.832 \\
\hline Cyprus & $\mathrm{CY}$ & 6 & 2012 & 3.124 & 3.721 \\
\hline Cyprus & $\mathrm{CY}$ & 9 & 2019 & 1.841 & 1.967 \\
\hline Czech Republic & $\mathrm{CZ}$ & 1 & 2002 & 1.287 & 1.429 \\
\hline Czech Republic & $\mathrm{CZ}$ & 2 & 2004 & 1.313 & 1.457 \\
\hline Czech Republic & $\mathrm{CZ}$ & 5 & 2011 & 1.597 & 1.846 \\
\hline Czech Republic & $\mathrm{CZ}$ & 6 & 2013 & 1.673 & 2.061 \\
\hline Czech Republic & $\mathrm{CZ}$ & 7 & 2014 & 1.078 & 1.165 \\
\hline Czech Republic & $\mathrm{CZ}$ & 8 & 2016 & 1.161 & 1.270 \\
\hline Czech Republic & $\mathrm{CZ}$ & 9 & 2018 & 1.288 & 1.391 \\
\hline Germany & $\mathrm{DE}$ & 1 & 2003 & 1.490 & 1.747 \\
\hline Germany & $\mathrm{DE}$ & 2 & 2004 & 1.354 & 1.457 \\
\hline Germany & $\mathrm{DE}$ & 3 & 2006 & 1.209 & 1.342 \\
\hline
\end{tabular}


Table 3 (continued)

\begin{tabular}{|c|c|c|c|c|c|}
\hline Country & Country ID & ESS round & Year & PPI(voters) & PPI \\
\hline Germany & $\mathrm{DE}$ & 4 & 2008 & 1.178 & 1.267 \\
\hline Germany & DE & 5 & 2010 & 1.335 & 1.419 \\
\hline Germany & $\mathrm{DE}$ & 6 & 2012 & 1.215 & 1.289 \\
\hline Germany & DE & 7 & 2014 & 1.251 & 1.263 \\
\hline Germany & $\mathrm{DE}$ & 8 & 2016 & 1.124 & 1.219 \\
\hline Germany & $\mathrm{DE}$ & 9 & 2018 & 1.228 & 1.308 \\
\hline Denmark & DK & 1 & 2002 & 1.376 & 1.493 \\
\hline Denmark & DK & 2 & 2004 & 1.435 & 1.527 \\
\hline Denmark & DK & 3 & 2006 & 1.628 & 1.733 \\
\hline Denmark & DK & 4 & 2008 & 1.564 & 1.630 \\
\hline Denmark & DK & 5 & 2010 & 1.645 & 1.696 \\
\hline Denmark & DK & 6 & 2013 & 1.334 & 1.515 \\
\hline Denmark & DK & 7 & 2014 & 1.303 & 1.423 \\
\hline Estonia & EE & 2 & 2004 & 1.129 & 1.390 \\
\hline Estonia & $\mathrm{EE}$ & 3 & 2005 & 1.028 & 0.974 \\
\hline Estonia & $\mathrm{EE}$ & 4 & 2008 & 1.384 & 1.629 \\
\hline Estonia & $\mathrm{EE}$ & 5 & 2011 & 1.426 & 1.660 \\
\hline Estonia & $\mathrm{EE}$ & 6 & 2012 & 1.511 & 1.940 \\
\hline Estonia & $\mathrm{EE}$ & 7 & 2014 & 1.279 & 1.478 \\
\hline Estonia & $\mathrm{EE}$ & 8 & 2016 & 1.071 & 1.217 \\
\hline Estonia & $\mathrm{EE}$ & 9 & 2018 & 1.145 & 1.300 \\
\hline Spain & ES & 1 & 2002 & 1.873 & 2.010 \\
\hline Spain & ES & 2 & 2004 & 1.404 & 1.424 \\
\hline Spain & ES & 3 & 2006 & 1.500 & 1.577 \\
\hline Spain & ES & 4 & 2008 & 1.808 & 1.911 \\
\hline Spain & ES & 5 & 2011 & 1.978 & 2.302 \\
\hline Spain & ES & 6 & 2013 & 2.740 & 3.247 \\
\hline Spain & ES & 7 & 2014 & 2.899 & 3.182 \\
\hline Spain & ES & 8 & 2017 & 2.309 & 2.469 \\
\hline Spain & ES & 9 & 2019 & 1.725 & 1.464 \\
\hline Finland & FI & 1 & 2002 & 1.053 & 1.094 \\
\hline Finland & FI & 2 & 2004 & 1.047 & 0.970 \\
\hline Finland & FI & 3 & 2006 & 1.035 & 1.011 \\
\hline Finland & FI & 4 & 2008 & 1.271 & 1.292 \\
\hline Finland & FI & 5 & 2010 & 1.225 & 1.375 \\
\hline Finland & FI & 6 & 2012 & 1.198 & 1.236 \\
\hline Finland & FI & 7 & 2014 & 1.274 & 1.197 \\
\hline Finland & FI & 8 & 2016 & 1.371 & 1.479 \\
\hline Finland & FI & 9 & 2018 & 1.290 & 1.359 \\
\hline France & FR & 1 & 2003 & 1.403 & 1.390 \\
\hline France & FR & 2 & 2004 & 1.297 & 1.333 \\
\hline France & FR & 3 & 2006 & 1.537 & 1.595 \\
\hline France & FR & 4 & 2008 & 1.832 & 2.027 \\
\hline France & FR & 5 & 2010 & 1.873 & 2.206 \\
\hline
\end{tabular}


Table 3 (continued)

\begin{tabular}{|c|c|c|c|c|c|}
\hline Country & Country ID & ESS round & Year & PPI(voters) & PPI \\
\hline France & FR & 6 & 2013 & 1.562 & 1.685 \\
\hline France & FR & 7 & 2014 & 1.747 & 1.815 \\
\hline France & FR & 8 & 2016 & 1.567 & 1.593 \\
\hline France & FR & 9 & 2019 & 1.690 & 1.874 \\
\hline United Kingdom & GB & 1 & 2002 & 1.368 & 1.541 \\
\hline United Kingdom & GB & 2 & 2004 & 1.413 & 1.489 \\
\hline United Kingdom & GB & 3 & 2006 & 1.435 & 1.631 \\
\hline United Kingdom & GB & 4 & 2008 & 1.503 & 1.639 \\
\hline United Kingdom & GB & 5 & 2010 & 1.495 & 1.708 \\
\hline United Kingdom & GB & 6 & 2012 & 1.455 & 1.672 \\
\hline United Kingdom & GB & 7 & 2014 & 1.451 & 1.826 \\
\hline United Kingdom & GB & 8 & 2016 & 1.431 & 1.563 \\
\hline United Kingdom & GB & 9 & 2018 & 1.511 & 1.629 \\
\hline Greece & GR & 1 & 2003 & 1.939 & 1.993 \\
\hline Greece & GR & 2 & 2005 & 1.787 & 1.886 \\
\hline Greece & GR & 4 & 2006 & 2.609 & 2.982 \\
\hline Greece & GR & 5 & 2011 & 2.208 & 3.245 \\
\hline Croatia & HR & 4 & 2008 & 1.918 & 2.384 \\
\hline Croatia & HR & 5 & 2011 & 1.965 & 2.506 \\
\hline Croatia & HR & 9 & 2019 & 1.426 & 1.946 \\
\hline Hungary & $\mathrm{HU}$ & 1 & 2002 & 1.584 & 1.768 \\
\hline Hungary & $\mathrm{HU}$ & 2 & 2005 & 1.666 & 1.961 \\
\hline Hungary & $\mathrm{HU}$ & 3 & 2006 & 2.805 & 3.272 \\
\hline Hungary & $\mathrm{HU}$ & 4 & 2009 & 2.735 & 4.230 \\
\hline Hungary & $\mathrm{HU}$ & 5 & 2010 & 1.963 & 1.970 \\
\hline Hungary & $\mathrm{HU}$ & 6 & 2012 & 1.708 & 2.511 \\
\hline Hungary & $\mathrm{HU}$ & 7 & 2014 & 2.085 & 2.360 \\
\hline Hungary & HU & 8 & 2017 & 2.127 & 2.562 \\
\hline Hungary & $\mathrm{HU}$ & 9 & 2019 & 2.568 & 3.284 \\
\hline Ireland & IE & 1 & 2002 & & \\
\hline Ireland & IE & 2 & 2005 & 1.346 & 1.443 \\
\hline Ireland & IE & 3 & 2007 & 1.361 & 1.430 \\
\hline Ireland & IE & 4 & 2009 & 1.564 & 2.082 \\
\hline Ireland & IE & 5 & 2011 & 1.223 & 1.383 \\
\hline Ireland & IE & 6 & 2012 & 1.249 & 1.617 \\
\hline Ireland & IE & 7 & 2014 & 1.309 & 1.510 \\
\hline Ireland & IE & 8 & 2017 & 1.169 & 1.435 \\
\hline Ireland & IE & 9 & 2019 & 1.153 & 1.366 \\
\hline Israel & IL & 1 & 2003 & 1.429 & 1.657 \\
\hline Israel & IL & 4 & 2009 & 1.071 & 1.176 \\
\hline Israel & IL & 5 & 2011 & 1.253 & 1.430 \\
\hline Israel & IL & 6 & 2012 & 1.307 & 1.438 \\
\hline Israel & IL & 7 & 2015 & 1.447 & 1.495 \\
\hline Israel & IL & 8 & 2016 & 1.683 & 1.828 \\
\hline
\end{tabular}


Table 3 (continued)

\begin{tabular}{|c|c|c|c|c|c|}
\hline Country & Country ID & ESS round & Year & PPI(voters) & PPI \\
\hline Iceland & IS & 6 & 2012 & 1.658 & 2.210 \\
\hline Iceland & IS & 8 & 2017 & 1.709 & 1.970 \\
\hline Italy & IT & 1 & 2003 & 1.755 & 2.040 \\
\hline Italy & IT & 6 & 2013 & 1.330 & 1.382 \\
\hline Italy & IT & 8 & 2017 & 1.524 & 1.825 \\
\hline Italy & IT & 9 & 2018 & 1.499 & 1.694 \\
\hline Lithuania & LT & 5 & 2011 & 1.620 & 1.877 \\
\hline Lithuania & LT & 6 & 2013 & 1.033 & 1.138 \\
\hline Lithuania & LT & 7 & 2014 & 1.224 & 1.005 \\
\hline Lithuania & LT & 8 & 2017 & 1.060 & 1.161 \\
\hline Lithuania & LT & 9 & 2019 & 0.985 & 1.059 \\
\hline Luxembourg & LU & 1 & 2003 & 1.208 & 1.222 \\
\hline Luxembourg & LU & 2 & 2004 & 0.978 & 0.976 \\
\hline Netherlands & NL & 1 & 2002 & 1.270 & 1.363 \\
\hline Netherlands & NL & 2 & 2004 & 1.434 & 1.527 \\
\hline Netherlands & NL & 3 & 2007 & 1.198 & 1.251 \\
\hline Netherlands & NL & 4 & 2008 & 1.147 & 1.213 \\
\hline Netherlands & NL & 5 & 2011 & 1.218 & 1.252 \\
\hline Netherlands & NL & 6 & 2012 & 1.147 & 1.188 \\
\hline Netherlands & NL & 7 & 2014 & 1.117 & 1.186 \\
\hline Netherlands & NL & 8 & 2016 & 1.092 & 1.209 \\
\hline Netherlands & NL & 9 & 2018 & 1.202 & 1.252 \\
\hline Norway & NO & 1 & 2002 & 1.285 & 1.418 \\
\hline Norway & NO & 2 & 2004 & 1.350 & 1.454 \\
\hline Norway & NO & 3 & 2006 & 1.293 & 1.427 \\
\hline Norway & NO & 4 & 2008 & 1.343 & 1.439 \\
\hline Norway & NO & 5 & 2010 & 1.363 & 1.412 \\
\hline Norway & NO & 6 & 2012 & 1.313 & 1.374 \\
\hline Norway & NO & 7 & 2014 & 1.367 & 1.408 \\
\hline Norway & NO & 8 & 2016 & 1.332 & 1.380 \\
\hline Norway & NO & 9 & 2019 & 1.360 & 1.435 \\
\hline Poland & PL & 1 & 2002 & 1.522 & 1.852 \\
\hline Poland & PL & 2 & 2004 & 1.205 & 1.702 \\
\hline Poland & PL & 3 & 2006 & 1.765 & 2.490 \\
\hline Poland & PL & 4 & 2008 & 1.457 & 1.836 \\
\hline Poland & PL & 5 & 2010 & 1.529 & 1.784 \\
\hline Poland & PL & 6 & 2012 & 1.730 & 2.379 \\
\hline Poland & PL & 7 & 2014 & 1.585 & 2.275 \\
\hline Poland & PL & 8 & 2016 & 2.499 & 3.106 \\
\hline Poland & PL & 9 & 2018 & 2.298 & 3.019 \\
\hline Portugal & PT & 1 & 2002 & 2.116 & 2.131 \\
\hline Portugal & PT & 2 & 2004 & 1.709 & 1.710 \\
\hline Portugal & PT & 3 & 2006 & 1.225 & 1.266 \\
\hline Portugal & PT & 4 & 2008 & 1.541 & 1.577 \\
\hline
\end{tabular}


Table 3 (continued)

\begin{tabular}{|c|c|c|c|c|c|}
\hline Country & Country ID & ESS round & Year & PPI(voters) & PPI \\
\hline Portugal & PT & 5 & 2010 & 1.693 & 1.837 \\
\hline Portugal & PT & 6 & 2012 & 2.254 & 2.566 \\
\hline Portugal & PT & 8 & 2017 & 1.390 & 1.358 \\
\hline Portugal & PT & 9 & 2019 & 1.514 & 1.465 \\
\hline Russian Federation & RU & 3 & 2006 & 1.269 & 1.373 \\
\hline Russian Federation & RU & 4 & 2008 & 1.340 & 1.410 \\
\hline Russian Federation & RU & 5 & 2011 & 1.204 & 1.326 \\
\hline Russian Federation & RU & 6 & 2012 & 1.383 & 1.497 \\
\hline Russian Federation & RU & 8 & 2017 & 1.263 & 1.314 \\
\hline Sweden & SE & 1 & 2002 & 1.247 & 1.281 \\
\hline Sweden & SE & 2 & 2004 & 1.288 & 1.338 \\
\hline Sweden & SE & 3 & 2006 & 1.363 & 1.398 \\
\hline Sweden & SE & 4 & 2009 & 1.578 & 1.682 \\
\hline Sweden & SE & 5 & 2010 & 1.514 & 1.520 \\
\hline Sweden & SE & 6 & 2012 & 1.535 & 1.589 \\
\hline Sweden & SE & 7 & 2015 & 1.327 & 1.342 \\
\hline Sweden & SE & 8 & 2016 & 1.264 & 1.414 \\
\hline Sweden & SE & 9 & 2019 & 1.383 & 1.416 \\
\hline Slovenia & SI & 1 & 2002 & 1.276 & 1.524 \\
\hline Slovenia & SI & 3 & 2006 & 1.496 & 1.757 \\
\hline Slovenia & SI & 4 & 2008 & 0.619 & 0.564 \\
\hline Slovenia & SI & 5 & 2010 & 1.523 & 1.953 \\
\hline Slovenia & SI & 6 & 2012 & 2.071 & 2.778 \\
\hline Slovenia & SI & 7 & 2014 & 1.305 & 1.445 \\
\hline Slovenia & SI & 8 & 2016 & 1.194 & 1.309 \\
\hline Slovenia & SI & 9 & 2018 & 1.450 & 1.406 \\
\hline Slovakia & SK & 2 & 2004 & 1.625 & 1.903 \\
\hline Slovakia & SK & 3 & 2006 & 1.369 & 1.431 \\
\hline Slovakia & SK & 4 & 2008 & 1.391 & 1.583 \\
\hline Slovakia & SK & 5 & 2010 & 1.671 & 1.872 \\
\hline Slovakia & SK & 6 & 2012 & 1.373 & 1.477 \\
\hline Slovakia & SK & 9 & 2019 & 1.422 & 1.645 \\
\hline Turkey & $\mathrm{TR}$ & 2 & 2004 & 1.900 & 2.251 \\
\hline Turkey & $\mathrm{TR}$ & 4 & 2009 & 2.252 & 2.583 \\
\hline Ukraine & UA & 2 & 2005 & 1.336 & 1.412 \\
\hline Ukraine & UA & 3 & 2006 & 1.363 & 1.294 \\
\hline Ukraine & UA & 4 & 2009 & 2.342 & 2.445 \\
\hline Ukraine & UA & 5 & 2011 & 1.653 & 2.149 \\
\hline Ukraine & UA & 6 & 2012 & 1.637 & 2.126 \\
\hline
\end{tabular}


Funding Open access funding provided by Centre for Social Sciences. This work was supported by the Ministry for Innovation and Technology from the source of the National Research, Development and Innovation Fund [grant numbers: ÚNKP-20-5-CORVINUS-45; ÚNKP-21-5-CORVINUS-128; FK 137755]. Veronika Patkós is a recipient of the Bolyai János Research Fellowship of the Hungarian Academy of Sciences [grant number: BO/419/19].

Data availability All data used in this paper are publicly available.

Code availability (software application or custom code) Codes are available on request.

\section{Declarations}

Conflict of interest The author declares that she has no conflict of interest.

Open Access This article is licensed under a Creative Commons Attribution 4.0 International License, which permits use, sharing, adaptation, distribution and reproduction in any medium or format, as long as you give appropriate credit to the original author(s) and the source, provide a link to the Creative Commons licence, and indicate if changes were made. The images or other third party material in this article are included in the article's Creative Commons licence, unless indicated otherwise in a credit line to the material. If material is not included in the article's Creative Commons licence and your intended use is not permitted by statutory regulation or exceeds the permitted use, you will need to obtain permission directly from the copyright holder. To view a copy of this licence, visit http://creativecommons.org/licenses/by/4.0/.

\section{References}

Anduiza, E., Gallego, A., Muñoz, J.: Turning a blind eye experimental evidence of partisan bias in attitudes toward corruption. Comp. Polit. Stud. 46, 1664-1692 (2013). https://doi.org/10.1177/0010414013 489081

Bafumi, J., Shapiro, R.Y.: A new partisan voter. J. Polit. 71, 1-24 (2009). https://doi.org/10.1017/S0022 381608090014

Baldassarri, D., Gelman, A.: Partisans without constraint: political polarization and trends in American public opinion. AJS 114, 408-446 (2008). https://doi.org/10.2139/ssrn.1010098

Bartels, L.M.: Beyond the running tally: Partisan bias in political perceptions. Polit. Behav. 24, 117-150 (2002). https://doi.org/10.1023/A:1021226224601

Bisgaard, M.: Bias will find a way: Economic perceptions, attributions of blame, and partisan-motivated reasoning during crisis. J. Polit. 77, 849-860 (2015). https://doi.org/10.1086/681591

Boxell, L., Gentzkow, M., Shapiro, J.M.: Cross-country trends in affective polarization. National Bureau of Economic Research (2020)

Dalton, R.J., Weldon, S.: Partisanship and party system institutionalization. Party Polit. 13, 179-196 (2007). https://doi.org/10.1177/1354068807073856

DiMaggio, P., Evans, J., Bryson, B.: Have American's social attitudes become more polarized? Am. J. Sociol. 102, 690-755 (1996)

Druckman, J.N., Levendusky, M.S.: What do we measure when we measure affective polarization? Public Opin. q. 83, 114-122 (2019)

Esteban, J.-M., Ray, D.: On the measurement of polarization. Econom. J. Econom. Soc. 62, 819-851 (1994). https://doi.org/10.2307/2951734

European Social Survey: ESS 1-9, European Social Survey Cumulative File, Study Description. Bergen: NSD - Norwegian Centre for Research Data for ESS ERIC., doi:https://doi.org/10.21338/NSD-ESSCUMULATIVE.

Fiorina, M.P., Abrams, S.J., Pope, J.C.: Culture war? Pearson Longman, New York (2005)

Frye, T.: The perils of polarization. Economic performance in the postcommunist world. World Polit. 54, 308-337 (2002). https://doi.org/10.1353/wp.2002.0008

Gidron, N., Adams, J., Horne, W.: Toward a comparative research agenda on affective polarization in mass publics. APSA Comp. Polit. Newsl. 29, 30-36 (2019)

Goldstone, J.A., Ulfelder, J.: How to construct stable democracies. Wash. q. 28, 7-20 (2004)

Green, D.P., Palmquist, B., Schickler, E.: Partisan hearts and minds: Political parties and the social identities of voters. Yale University Press (2004) 
Hernandez, E., Anduiza, E., Rico, G.: Affective polarization and the salience of elections. Elect. Stud. 69, 102203 (2020)

Hetherington, M.J.: Putting polarization in perspective. Br. J. Polit. Sci. 39, 413-448 (2009)

Iyengar, S., Sood, G., Lelkes, Y.: Affect, not ideology a social identity perspective on polarization. Public Opin. q. 76, 405-431 (2012). https://doi.org/10.1093/poq/nfs038

Jacobson, G.C.: Partisan polarization in presidential support: The electoral connection. Cong. Presidency: J. Capital Stud. 30, 1-36 (2003)

Jacobson, G.C.: Perception, memory, and partisan polarization on the Iraq War. Polit. Sci. q. 125, 31-56 (2010). https://doi.org/10.1002/j.1538-165X.2010.tb00667.x

Jacobson, G.C.: Partisan polarization in American politics: a background paper. Pres. Stud. q. 43, 688-708 (2013). https://doi.org/10.1111/psq.12062/full

Jerit, J., Barabas, J.: Partisan perceptual bias and the information environment. J. Polit. 74, 672-684 (2012)

Knudsen, E.: Affective polarization in multiparty systems? comparing affective polarization towards voters and parties in Norway and the United States. Scand. Polit. Stud. 44, 34-44 (2020). https://doi.org/10. 1111/1467-9477.12186

Körösényi, András: Political polarization and its consequences on democratic accountability. Corvinus J. Soc. Soc. Policy 4(2), 3-30 (2013). https://doi.org/10.14267/cjssp.2013.02.01

Lauka, A., McCoy, J., Firat, R.B.: Mass partisan polarization: measuring a relational concept. Am. Behav. Sci. 62, 107-126 (2018)

Lelkes, Y., Westwood, S.J.: The limits of partisan prejudice. J. Polit. 79, 485-501 (2017)

Martini, S., Torcal, M.: Trust across political conflicts: evidence from a survey experiment in divided societies. Party Polit. 25, 126-139 (2019)

Mason, L.: The rise of uncivil agreement: Issue versus behavioral polarization in the American electorate. Am. Behav. Sci. 57, 140-159 (2013)

Mason, L.: "I disrespectfully agree": the differential effects of partisan sorting on social and issue polarization. Am. J. Polit. Sci. 59, 128-145 (2015)

McCoy, J., Rahman, T., Somer, M.: Polarization and the global crisis of democracy: common patterns, dynamics, and pernicious consequences for democratic polities. Am. Behav. Sci. 62, 16-42 (2018)

Orr, L.V., Huber, G.A.: The policy basis of measured partisan animosity in the United States. Am. J. Polit. Sci. 64, 569-586 (2020)

Patkós V.: Szekértáborharc. Eredmények a politikai megosztottság okairól és következményeiről. TK PTI Napvilág, Budapest (2019)

Patkós, V., Plesz, B.: European Government-Opposition Voters (EGOV) Data Set. 1, (2021). doi: 10.6084/ m9.figshare. 14061152

Reiljan, A.: 'Fear and loathing across party lines'(also) in Europe: affective polarisation in European party systems. Eur. J. Polit. Res. 59, 376-396 (2020)

Rose, R., Mishler, W.: Negative and positive party identification in post-communist countries. Elect. Stud. 17, 217-234 (1998). https://doi.org/10.1016/S0261-3794(98)00016-X

Shani, D.: On the origins of political interest. Princeton University (2009)

Slater, D., Arugay, A.A.: Polarizing figures: Executive power and institutional conflict in Asian democracies. Am. Behav. Sci. 62, 92-106 (2018)

Somer, M., McCoy, J.: Transformations through polarizations and global threats to democracy. SAGE Publications Sage CA, Los Angeles, CA (2019)

Stanig, P.: Political polarization in retrospective economic evaluations during recessions and recoveries. Elect. Stud. 32, 729-745 (2013)

Stoker, L., Jennings, M.K.: Of time and the development of partisan polarization. Am. J. Polit. Sci. 52, 619-635 (2008)

Street, 1615a L., NW, Washington, S. 800, Inquiries, D. 200362024194300 | M. 2024194349 | F. 202419 4372 । M.: Political Polarization in the American Public, http://www.people-press.org/2014/06/12/polit ical-polarization-in-the-american-public/, (2014)

Street, 1615b L., NW, Washington, S. 800, Inquiries, D. 200362024194300 | M. 2024194349 | F. 202419 4372 I M.: Partisanship and Political Animosity in 2016, http://www.people-press.org/2016/06/22/parti sanship-and-political-animosity-in-2016/, (2016)

Wagner, M.: Affective polarization in multiparty systems. Elect. Stud. 69, 102199 (2021). https://doi.org/10. 1016/j.electstud.2020.102199

Ward, D.G., Tavits, M.: How partisan affect shapes citizens' perception of the political world. Elect. Stud. 60, 102045 (2019)

Publisher's Note Springer Nature remains neutral with regard to jurisdictional claims in published maps and institutional affiliations. 